\title{
PERANCANGAN BUKU JURNAL PEMBELAJARAN 'BERMAIN DENGAN SERIOEUS' : MEDIA PEMBELAJARAN PADA MATA KULIAH METODOLOGI DESAIN
}

\author{
Siti Nurannisaa P.B. \\ Fakulas Seni Rupa dan Desain, Universitas Tarumanagara Jakarta \\ sitip@fsrd.untar.ac.id/sitinurannisaa@gmail.com
}

\begin{abstract}
Abstrak
Media pembelajaran merupakan salah satu faktor dalam mendukung keberhasilan dalam proses pembelajaran. Penelitian ini bertujuan untuk mengembangkan media pembelajaran dalam proses desain, khususnya pada jurusan Desain Komunikasi Visual. Jurnal Pembelajaran digunakan sebagai media pembelajaran, penelitian ini dilakukan berdasarkan studi kasus di Mata Kuliah Desain Metodologi. Jurnal digunakan sebagai media dalam kegiatan dikelas, aktivitas instruksional dirancang berupa jurnal pembelajaran bernama 'Bermain Dengan Serioeus'. Jurnal pembelajaran adalah kumpulan catatan, pengamatan, pengalaman dan bahan lainnya yang relevan dan terkait selama periode waktu proses pembelajaran. Pembelajaran melalui refleksi pengalaman, mengembangkan kompetensi siswa dalam memahami proses desain. Penelitian ini merupakan pengembangan research and development ( $R \& D$ model) yang bertujuan menghasilkan produk berupa prototipe desain media pembelajaran Jurnal Pembelajaran. Data diambil dari hasil observasi dan dianalisis secara deskriptif kualitatif. Jurnal pembelajaran memiliki potensi yang baik untuk meningkatkan minat dan keterlibatan siswa dengan materi pelajaran, mendorong dan memberdayakan siswa untuk membangun pembelajaran mereka sendiri dan lebih reflektif dalam studi. Dengan media ini diharapkan siswa lebih mudah memahami bagaimana melihat pengalamannya sendiri dalam proses desain.
\end{abstract}

Kata Kunci: jurnal, pembelajaran, desain, proses, kreatif

\begin{abstract}
Learning media is one factor in supporting the success in the learning process. This research aims to develop instructional tools in the design process, especially on the Visual Communication Design majors. Learning Journal used as a medium in the learning process, this research is based on case studies in Design Methodology course. Journals are used as a medium in class activities; instructional activity is designed as a learning journal called 'Bermain Dengan Serioeus'. Learning Journal is a collection of notes, observations, experiences and other relevant materials and associated during the period of the learning process. Learning through reflection experience, develop student competencies in understanding the process of design and creative thinking. This research is a research and development ( $R \& D$ model) which aims to produce a prototype design of instructional Learning Journal media. The main data captured from the results of observations and analyzed descriptively qualitative. Learning journal has a good potential to increase student interest and involvement with the subject, encourage and empower students to build their own learning and more reflective in the study. This medium is expected students more easily understand how to look at their own experience in the design process.
\end{abstract}

Keywords: journal, learning, design, process, creative 


\section{PENDAHULUAN}

Pembelajaran desain merupakan salah satu proses transfer ilmu yang tidak cukup hanya dilaksanakan dengan cara satu arah. Diperlukan upaya aktif secara dua arah antara pengajar dan mahasiswa dalam membangun pengalaman atau pengetahuan yang telah dimiliki sebelumnya. Siswa yang aktif terlibat dengan apa yang mereka pelajari cenderung akan memahami lebih banyak, belajar lebih banyak, mengingat lebih banyak, menikmati lebih banyak dan lebih mampu membuat hubungan mengenai apa yang telah mereka pelajari, dari pada siswa yang pasif, hanya menerima satu arah dari apa yang disampaikan oleh pengajar (Park, 2003:183). Dalam proses pembelajaran di sekolah desain, keaktifan siswa adalah salah satu kemampuan yang memudahkan mereka dalam mempelajari materi terkait pengetahuan proses perancangan desain dan memecahkan masalah melalui cara berpikir kreatif. Proses belajar akan sangat mempengaruhi bagaimana munculnya keinginan siswa untuk belajar. Mengajarkan proses kreatif perlu diikuti dengan aktivitas dalam kelas yang memicu kemampuan keterampilan berpikir kreatif yang terintegrasi delam proses pembelajaran.

Meningkatkan keaktifan siswa dalam belajar proses berpikir kreatif dapat dilakukan apabila siswa dapat mengambil makna dari materi yang telah disampaikan dikelas. Pembelajaran bermakna menurut Ausubel (1960:267) merupakan proses mengaitkan informasi atau materi baru dengan konsep-konsep yang telah ada dalam struktur kognitif. Untuk terjadinya belajar bermakna maka para perancang pembelajaran harus mengetahui dan menggali konsep-konsep yang telah dimiliki peserta didik sebelumnya. Kemudian membantu memadukannya secara harmonis dengan pengetahuan baru yang akan dipelajari sehingga berhubungan dengan pengetahuan yang dimiliki sebelumnya (Warsita, 2008:72). Dengan demikian proses pembelajaran kelas perlu diciptakan sedemikian rupa untuk menstimulasi mahasiswa dalam membangun pengetahuannya sendiri dalam mempelajari proses berpikir kreatif melalui aktivitas pembelajaran yang bermakna.

Seorang desainer perlu mengetahui bagaimana membangun metode berpikir sesuai dengan proses permasalahan desain dan metode pemecahan masalah tertentu. Memilih dan mengembangkan kemampuan menganalisa dan membaca gejala secara kritis dari berbagai perubahan yang terjadi di sekeliling. Metodologi Desain adalah mata kuliah yang mengajarkan struktur berpikir dalam membangun metode dan memproses permasalahan desain, mata kuliah ini bertujuan agar setiap siswa dapat mempelajari proses desain melalui pegalamannya. Metode desain harus dipelajari ketimbang diajarkan, masing-masing kita harus menemukan proses kita sendiri, karena kitalah, dan bukan orang lain, yang harus mendesainnya (Lawson,1980:4). Dengan bentuk masalah yang sedemikian kompleks, maka pembelajaran pada mata kuliah Metodologi Desain harus diajarkan menggunakan metode pendekatan yang bersifat fleksibel melalui pengalaman langsung atau praktek, sehingga mahasiswa dapat mengenali kekhasan pada proses desainnya masing-masing. 
Mempelajari sebuah proses desain memerlukan aktivitas secara praktek. "Design is a process that turns a brief or requirement into a finished product or design solution." (Ambrose \& Harris, 2010:10). Pembelajaran praktek merupakan suatu proses untuk meningkatkan keterampilan mahasiswa dengan menggunakan berbagai metode yang sesuai dengan keterampilan yang diberikan dan peralatan yang digunakan. Salah satu aktivitas pembelajaran yang dapat dilakukan dalam mengajarkan mata kuliah Metodologi Desain ini adalah dengan menggunakan media pembelajaran yang dapat menstimulasi pembelajaran bermakna bagi mahasiswa. Media yang dapat membantu mereka untuk membangun dan membuat keterkaitan antara pengetahuan proses desain dan berpikir kreatif yang sudah ada pada dirinya sesuai dengan materi pembelajaran yang ada dikelas.

Penelitian ini bertujuan membuat pengembangan perancangan media pembelajaran yang mampu meningkatkan pemahaman mengenai materi proses desain. Media pembelajaran yang dikembangkan melalui penelitian ini adalah berupa 'jurnal pembelajaran' yang merupakan kumpulan dari catatan, pengamatan, pengalaman dan bahan lain yang relevan selama periode waktu dan masa studi, atau pengalaman belajar. Isi dalam jurnal pelajaran berisi pertanyaan tentang materi, ide-ide atau proses berpikir tentang apa yang terjadi dalam periode kelas tertentu. Media 'jurnal pembelajaran' yang dirancang akan menggunakan contoh nyata dari kejadian dan kehidupan nyata yang ditemui sehari-hari. Buku ini akan menjadi panduan mahasiswa dalam menemukan informasi baru, melalui pengalaman dalam membangun pengetahuan mereka sendiri tentang materi yang diberikan dalam kelas.

\section{METODE PENELITIAN}

Jenis penelitian yang dipilih adalah Penelitian dan Pengembangan atau Research and Development (R\&D) yaitu rangkaian proses atau langkah-langkah dalam rangka mengembangkan suatu produk baru tertentu atau menyempurnakan produk yang telah ada agar dapat dipertanggung jawabkan (Sugiono, 2010:407). Model pengembangan yang menjadi acuan peneliti yaitu Model ADDIE yang mencakup aspek Analyze (analisis), Design (perancangan), Development (pengembangan), Implementation (penerapan), dan Evaluation (penilaian). Model research and development ini di kombinasikan karena di sesuaikan dengan langkah-langkah dalam proses penelitian dan pengembangan yang dilakukan.

Data utama (primer) pada penelitian ini diambil langsung dari hasil observasi lapangan berupa SAP, modul perkuliahan dan tugas mahasiswa. Data dianalisis secara deskriptif kualitatif dengan langkah-langkah berikut; pemaparan dan membuat deskripsi data menggunakan materi hasil observasi tersebut. Berikut bagan model yang dilakukan : 


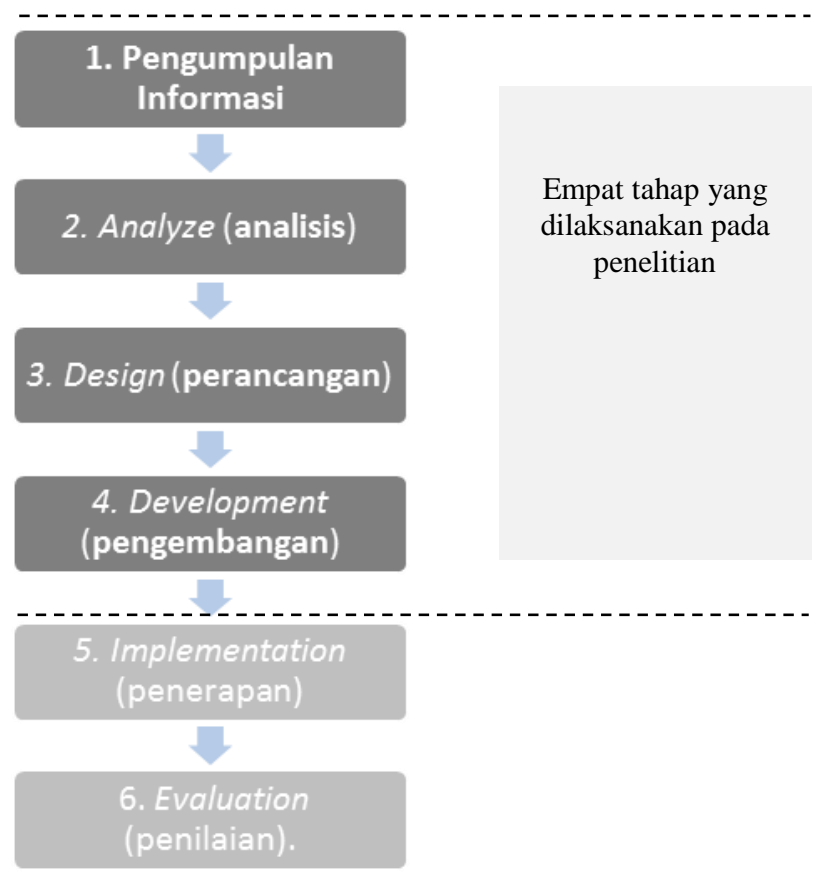

Bagan 1. Tahap Pengembangan Model ADDIE

Berdasarkan bagan diatas, maka model ADDIE pada penelitian ini hanya akan dilakukan sampai dengan tahap tiga yaitu development (pengembangan). Tahap awal yang dilakukan adalah, pengumpulan informasi data observasi. Kemudian dilanjutkan dengan tahap pertama model ADDIE yaitu tahap Analyze (analisis) disajikan sebagai input (masukan) pada tahap desain. Hasil tersebut diubah menjadi bahan untuk Design (perancangan) desain media pembelajaran yang akan dibuat. Selanjutnya, desain tersebut disajikan pada tahap Development (pengembangan), digunakan untuk menuntun pada pemilihan atau pembuatan materi pada media pembelajaran yang dibuat.

\section{HASIL DAN PEMBAHASAN}

Bagian pertama dari pembahasan akan menjelaskan beberapa tinjauan terkait media dan jurnal pembelajaran, dilanjutkan tentang proses perancangan media pembelajaran, dan jurnal pembelajaran. Bagian kedua akan menjelaskan mengenai hasil rancangan, proses penggunaan dan cara penilaian untuk mengetahui tentang kemampuan siswa dalam menjawab pertanyaan.

\subsection{Media Pembelajaran}

Pembelajaran adalah pengembangan pengetahuan, keterampilan, atau sikap baru saat seseorang individu berinteraksi dengan informasi dan lingkungannya. Pada proses pembelajaran terdapat dua unsur yang sangat penting yaitu metode mengajar dan media pembelajaran. Kedua aspek ini saling berkaitan. Media pembelajaran merupakan salah satu komponen penting dalam pelaksanaan proses pembelajaran yang optimal. Media pembelajaran secara umum merupakan alat bantu proses belajar mengajar. Media adalah segala sesuatu yang dapat digunakan untuk menyalurkan pesan dari pengirim ke penerima sehingga dapat merangsang pikiran, 
perasaan perhatian dan minat serta perhatian siswa sedemikian rupa sehingga proses belajar terjadi (Sadiman, 2009:7). Media merupakan bagian yang tidak terpisahkan dari proses pembelajaran demi tercapainya tujuan pembelajaran. Salah satu fungsi utama media pengajaran adalah sebagai alat bantu mengajar yang turut mempengaruhi iklim, kondisi, dan lingkungan belajar.

Mempelajari sebuah proses desain memerlukan upaya latihan yang dapat mengeluarkan kemampuan pengenalan diri sendiri. Proses desain adalah sebuah proses berpikir untuk menciptakan atau mengkreasikan sesuatu dengan pengetahuan, pengalaman dan juga kemampuan inderawi yang dimiliki oleh diri. Proses ini menuntut seorang desainer untuk dapat memahami bagaimana dirinya membuat sebuah rancangan. Bagaimana merancang menggunakan teori yang ada namun tetap bisa mengeluarkan kompetensi "khas" dirinya. Setiap desainer tidak akan melakukan proses perancangan dengan cara yang sama. Perbedaan masalah dan karakteristik sebagai seorang desainer akan mempengaruhi bagaimana ia bekerja. Dibutuhkan sebuah aktivitas pembelajaran yang sifatnya reflektif. Aktivitas yang mampu menstimulasi siswa dalam memahami proses yang terjadi pada dirinya, mengenali pengalaman yang sudah ada dalam memori hidupnya, dapat menjadi salah satu stimulus kekuatan diri sebagai seorang desainer.

Pemakaian media pembelajaran yang tepat dan kreatif dapat membangkitkan keinginan, minat, motivasi dan rangsangan kegiatan belajar. Seorang mahasiswa yang sudah mengalami peningkatan minat, akan lebih mudah bagi mereka untuk dapat membuat keterkaitan antara materi dengan pengetahuan dan pengalaman dalam dirinya. Jika hal ini terjadi maka sebuah pembelajaran yang bermakna dapat dilakukan dengan lebih optimal. Saat mahasiswa mengambil makna dari sebuah situasi pembelajaran, secara tidak langsung informasi atau pengetahuan yang didapat tidak akan berhenti sampai tingkat hapalan. Mereka dapat mengolah informasi tersebut untuk dilakukan secara praktika pada proses perancangan desain lainnya.

\subsection{Jurnal Pembelajaran}

Jurnal pembelajaran adalah kumpulan catatan, pengamatan, pengalaman dan bahan lainnya yang relevan dan terkait selama periode waktu proses pembelajaran. Tujuan dibuatnya jurnal adalah untuk meningkatkan pembelajaran melalui proses menulis dan berpikir tentang pengalaman belajar yang telah dilalui. Jurnal akan mencerminkan kepribadian dan pengalaman belajar seseorang. "A learning journal represents an accentuation of those right conditions - some guidance, some encouragement, helpful questions or exercises and the expectation that journal-writing can have a worthwhile consequence, whether during or at the end of the process, or as a result of both" (Moon, 2006:1). Sebuah jurnal pembelajaran pada dasarnya adalah sebuah media untuk refleksi diri atas suatu pengalaman belajar yang telah di tempuh sebelumnya. Beberapa tujuan penggunaan jurnal pembelajaran dalam kaitannya untuk merekam pengalaman :

1) Memfasilitasi belajar dari pengalaman

2) Mendukung pemahaman dan representasi pemahaman 
3) Mengembangkan pemikiran kritis atau pengembangan sikap ingin tahu

4) Meningkatkan keterlibatan aktif dalam pembelajaran

5) Meningkatkan kemampuan dalam refleksi dan pemikiran

6) Mendukung pengembangan pribadi dan pemberdayaan diri

7) Sarana pendukung perubahan perilaku

8) Meningkatkan kreativitas

9) Sarana ekspresi diri

10) Membina komunikasi, reflektif dan interaksi kreatif dalam kelompok

Refleksi merupakan orientasi untuk mengetahui bagaimana seseorang menjalani kehidupannya. Bukan menjalankan sesuatu secara otomatis atau dilakukan hanya apabila diminta untuk melakukan itu, misalnya dalam konteks belajar, dilakukan hanya untuk menghapal atau mengingat, atau dilakukan hanya apabila ada keperluan; seperti ujian. Mempelajari proses desain dan berpikir kreatif tidak seperti ini. Masing-masing dari kita (desainer) harus menemukan prosesnya sendiri, karena kitalah, dan bukan orang lain, yang akan melakukan proses desainnya. "Reflective activities like journal writing provides opportunities for the learner to reflect and write about new information or ideas, thus better understanding and remembering them" (Lew \& Schmidt, 2011:520). Proses refleksi merupakan bagian yang baik untuk mempelajari proses dan metode desain diri sendiri, yang berkualitas dan bermakna.

Dalam sebuah perancangan desain melibatkan berbagai proses. Selain memadukan antara seni dan sains, proses desain juga melibatkan proses mental si perancang (desainer) itu sendiri. Proses mental sangat berkaitan dengan bagaimana seorang desainer melakukan refleksi pada proses perancangan yang telah dilakukan. Sebuah jurnal pembelajaran dapat digunakan sebagai suatu media untuk belajar dari proses refleksi tersebut. Proses desain sangat erat kaitannya dengan pengalaman, sifat dan kepribadian desainer. Beberapa sifat yang perlu dimunculkan dalam proses desain, diantaranya adalah 1) minat dalam dunia visual, 2) rasa ingin tahu tentang komunikasi dalam segala bentuk, 3) kreativitas. Desainer juga perlu memiliki keingintahuan intelektual : memahami bagaimana komunikasi bekerja, berani saat mencoba ide, melakukan eksperimen dan hal-hal baru. Pengenalan sebuah proses desain yang terkait dengan pribadi diri, pemikiran, pengambilan keputusan, kemampuan memilah dan memilih dalam melakukan proses desain dapat dilakukan melalui penggunaan jurnal pembelajaran. Melihat dari tujuan dan fungsi jurnal pembelajaran, maka media tersebut dapat menjadi sarana mahasiswa untuk bisa mendalami sebuah proses desain.

\subsection{Mata Kuliah Metodologi Desain}

Metodologi Desain adalah mata kuliah ini berjenis teori yang dilaksanakan pada semester empat, dengan jumlah pertemuan 14 kali selama satu semester. Mata kuliah metodologi desain merupakan mata kuliah yang melatih siswa dalam membangun struktur berpikir dalam memproses permasalahan desain dengan cara dan urutan dalam mendesain. Metodologi desain sendiri memiliki pengertian, yaitu pendekatan 
terstruktur menggunakan cara dan urutan, prosedur, teknik, dan beberapa cara dalam proses perancangan dan penciptaan karya.

Beberapa materi utama dari mata kuliah ini adalah mengenai pembelajaran proses desain. Prosedur pembuatan konsep desain yang dilakukan oleh para desainer serta beberapa cara dalam eksplorasi gagasan melalui berbagai metode berpikir kreatif juga menjadi materi dalam mata kuliah tersebut. Mata kuliah ini bertujuan untuk melatih kejelian dalam melihat masalah, mengamati situasi lingkungan, merumuskan konsep dan membuat visualisasi dengan berbagai pendekatan.

\subsection{Jurnal Pembelajaran 'Bermain Dengan Serioeus'}

Jurnal Pembelajaran digunakan sebagai media ujian akhir semester (UAS). Jurnal pembelajaran ini akan merepresentasikan tentang mata kuliah Metodologi Desain yang telah dipelajari sebelumnya dalam kelas. Buku ini dirancang untuk menstimulasi siswa agar dapat membuat sebuah perjalanan mengenai proses pembelajaran desain. Berbagai hal dibuku ini akan melibatkan elemen proses kreatif, baik yang bersifat tepat dan tak pasti, sistematik dan acak, matematis dan imajinatif. Pada bagian ini akan dijelaskan dua tahap pembuatan jurnal pembelajaran yaitu (1) bagian pertama akan menjelaskan tentang proses perancangan Jurnal Pembelajaran 'Bermain Dengan Serioeus' dan (2) kedua, adalah hasil desain perancangan media jurnal pembelajaran beserta dengan konsep pembelajarannya.

\subsubsection{Proses Perancangan Jurnal Pembelajaran 'Bermain Dengan Serioeus'}

Proses perancangan berlandaskan pendekatan sistem yang disebut ADDIE. Model ADDIE merupakan singkatan dari Analysis, Design, Development or Production, Implementation or Delivery and Evaluations. Perancangan akan dilakukan menggunakan tiga tahap yaitu Analysis, Design, Development or Production. Dua tahap terakhir yaitu Implementation or Delivery and Evaluations yang merupakan tahap implementasi penggunaan jurnal dalam kelas akan dilakukan pada penelitian tahap berikutnya.

\section{a) Analysis (Analisis)}

Pada tahap ini dilakukan pra perencanaan perancangan produk media pembelajaran baru yang akan dikembangkan. Mengidentifikasi produk yang sesuai dengan sasaran peserta didik, tujuan belajar, materi pembelajaran, lingkungan belajar dan strategi penyampaian dalam pembelajaran. Pada hasil identifikasi ditemukan bahwa mata kuliah Metodologi Desain memiliki jenis mata kuliah teori dengan jumlah dua SKS. Jika dilihat dari tujuan pembelajaran yang dimiliki pada SAP (Satuan Acara Perkuliahan) dengan capaian pembelajaran atau learning outcome yang dihasilkan adalah ; siswa mampu merancang proses desain yang efektif dan kreatif sesuai dengan permasalahan yang ingin dipecahkan.

Capaian pembelajaran ini menunjukkan bahwa kemampuan yang harus dimiliki siswa adalah kemampuan merancang. Proses perancangan merupakan gambaran proses yang berlangsung dari suatu keadaan awal sampai suatu keadaan masa depan, yang 
dibayangkan dengan menjelaskan kegiatan-kegiatan yang dilakukan didalamnya. Oleh karena itu dalam proses pembelajaran siswa membutuhkan suatu media pembelajaran yang mampu menstimulasi kompetensi dalam membuat suatu proses perancangan desain. Sebuah Jurnal Pembelajaran diharapkan mampu menjadi salah satu solusi dalam mempelajari sebuah proses desain.

\section{b) Design (Desain)}

Tahap ini diawali dengan menyesuaikan rencana pembelajaran, rumusan tujuan pembelajaran dengan perangkat pembelajaran. Rancangan dibuat untuk masingmasing materi pembelajaran. Membuat petunjuk penerapan desain atau pembuatan visual media jurnal pembelajaran.

Tabel 1. Rencana Pembelajaran Mata Kuliah Metodologi Desain

[Sumber: Dokumen Penulis]

\begin{tabular}{|l|l|}
\hline \multicolumn{1}{|c|}{$\begin{array}{c}\text { Rencana } \\
\text { Pembelajaran }\end{array}$} & \multicolumn{1}{|c|}{ Keterangan } \\
\hline $\begin{array}{l}\text { Capaian pembelajaran } \\
\text { (learning outcome) }\end{array}$ & $\begin{array}{l}\text { Siswa mampu merancang proses desain sesuai dengan } \\
\text { permasalahan yang ingin dipecahkan melalui visual. }\end{array}$ \\
\hline Tujuan Instruksional & $\begin{array}{l}\text { Mampu merumuskan struktur berpikir yang sesuai } \\
\text { dalam memproses permasalahan desain dengan cara } \\
\text { dan urutan dalam mendesain. }\end{array}$ \\
\hline $\begin{array}{l}\text { Perangkat } \\
\text { Pembelajaran }\end{array}$ & Media : Jurnal Pembelajaran \\
\hline
\end{tabular}

Pilihan materi perkuliahan yang dibuat pada jurnal pembelajaran adalah materi yang disampaikan pada pertemuan pertama sampai menjelang UTS (Ujian Tengah Semester). Materi dibagi menjadi lima bagian sesuai dengan SAP (Satuan Acara Perkuliahan)

Tabel 2. Materi Perkuliahan Metodologi Desain [Sumber: Dokumen Penulis]

\begin{tabular}{|c|l|}
\hline Bagian & \multicolumn{1}{|c|}{ Materi } \\
\hline I & $\begin{array}{l}\text { Pengenalan pengertian, lingkup dan fungsi } \\
\text { Desain }\end{array}$ \\
\hline II & $\begin{array}{l}\text { Mengidentifikasikan definisi desain dan } \\
\text { metodologi }\end{array}$ \\
\hline III & $\begin{array}{l}\text { Pekerjaan dan Kompetensi desainer. Desainer, } \\
\text { Seniman, atau pekerja teknis }\end{array}$ \\
\hline IV & $\begin{array}{l}\text { Mengidentifikasi proses desain dan Pembuatan } \\
\text { Konsep Desain }\end{array}$ \\
\hline V & Tahapan prosedur pembuatan konsep desain \\
\hline
\end{tabular}


Setelah dilakukan perumusan hal apa saja yang perlu dibuat dari dokumen rencana pembelajaran, maka berikutnya dilakukan perancangan desain jurnal pembelajaran dibuat melalui beberapa tahap yaitu :

Tabel 3. Tahap Perancangan Jurnal Pembelajaran

[Sumber: Dokumen Penulis)

\begin{tabular}{|l|l|}
\hline \multicolumn{1}{|c|}{ Tahapan } & \multicolumn{1}{|c|}{ Aktivitas } \\
\hline Identifikasi & $\begin{array}{l}\text { Mendefinisikan ciri-ciri jurnal pembelajaran yang mampu } \\
\text { memberikan stimulasi pada siswa untuk dapat membangun } \\
\text { pemahaman dan refleksi dari proses belajar. Kata kunci yang } \\
\text { ditemukan yaitu “ekspresi bebas namun terarah". }\end{array}$ \\
\hline Konseptualisasi & $\begin{array}{l}\text { Dari data pustaka yang telah diidentifikasi sebelumnya, maka } \\
\text { jenis jurnal pembelajaran yang diambil adalah yang memiliki } \\
\text { ruang untuk berekspresi secara bebas, namun tetap sesuai } \\
\text { dengan rencana pembelajaran. }\end{array}$ \\
\hline Eksplorasi & $\begin{array}{l}\text { Percobaan berupa sketsa layout, dilakukan berdasarkan data } \\
\text { yang telah diperoleh. Pada tahapan ini dicoba berbagai } \\
\text { kemungkinan kunci visual hasil dari konseptualisasi dengan kata } \\
\text { kunci "ekspresi bebas namun terarah" melalui penamaan buku, } \\
\text { bentuk, pemilihan warna, proses digital, jenis layout, warna, } \\
\text { tipografi dan sebagainya. Pada eksplorasi ditemukan bahwa } \\
\text { bentukjurnal akan dibuat dengan gaya semacam doodle art. }\end{array}$ \\
\hline
\end{tabular}

\section{c) Development (Pengembangan)}

Pada tahap ini, konsep yang sudah disusun dalam tahap desain diwujudkan dalam produk yang akan dibuat. Berbasis pada hasil perencanaan rancangan, maka mulai dibuat produk yang sesuai dengan struktur model desain. Jurnal pembelajaran merupakan media berupa catatan berisi berbagai pertanyaan yang sifatnya menstimulasi siswa untuk berpikir secara struktur, kritis namun kreatif. Dibutuhkan keterlibatan siswa secara langsung dalam mengkombinasi pengalamannya dengan materi pembelajaran proses desain. Salah satu tujuan yang akan dicapai yaitu pengalaman berpikir untuk mencapai kompetensi pemahaman mengenai proses desain, bukan hanya menghafal fakta-fakta dan ide-ide.

Pertanyaan dirancang untuk merangsang siswa untuk mengingat materi pembelajaran, memahami, membuat koneksi, mengevaluasi, dan merefleksikannya dengan informasi/pengalaman yang mereka tahu untuk menemukan sebuah proses desain yang sesuai dengan karakter diri siswa. Belajar dengan membuat kesimpulan, mendapatkan informasi baru dan membangun pembelajaran bermakna, sehingga siswa mengetahui bagaimana seorang desainer menjalani kehidupannya. Menentukan hal apa yang siswa miliki dan apa yang perlu dikembangkan dalam proses desain. Minat dan referensi visual, rasa ingin tahu atau kreativitas. 
Desain Jurnal Pembelajaran menggunakan desain gaya doodle. Secara umum doodle sendiri memiliki makna menggambar atau pola sambil berpikir tentang sesuatu yang lain atau ketika seseorang merasa bosan. Doodle biasa dilakukan berbentuk gambar sederhana yang dapat memiliki makna representasi tertentu atau mungkin hanya bentuk-bentuk abstrak. Beberapa contoh yang ditemukan salah satunya adalah mencoret-coret di buku catatan sekolah, dilakukan apabila siswa sedang melamun atau kehilangan minat dalam kelas. Dalam mengisi jurnal pembelajaran, siswa dibebaskan mengisi dengan cara menulis atau menggambar dengan bentuk sederhana atau abstrak. Namun disisi lain, siswa juga diarahkan bahwa ekspresi yang dimunculkan tetap harus dapat dimengerti sebagai suatu informasi pengetahuan.

\section{d) Implementation (Implementasi) dan Evaluation (Evaluasi)}

Untuk mendapatkan mendapatkan umpan balik pada penerapan media pembelajaran ini maka kedua tahap ini akan dilakukan pada penelitian tahap selanjutnya.

\subsubsection{Hasil Desain Perancangan Jurnal Pembelajaran 'Bermain Dengan Serioeus'} Judul Buku; 'Bermain Dengan Serioeus'. Judul ini merupakan pengembangan dari konsep pada tahap desain yaitu "ekspresi bebas namun terarah". Isi jurnal pembelajaran dibagi menjadi lima bagian dari materi pelajaran yang ada pada dokumen SAP (Satuan Acara Perkuliahan).

Jurnal pembelajaran dibuat dalam; bentuk buku dengan ukuran A5, dibuat dengan warna monokrom hitam dan putih. Layout dibuat dengan gaya sircus layout penyajian pertanyaan dan beberapa objek visual tidak mengacu pada ketentuan baku. Komposisi gambar visualnya dan teks disusun berdasarkan kebutuhan penyampian materi. Tipografi menggunakan jenis huruf dengan gaya tulisan tangan, untuk memberikan kesan non formal dan bebas. Proses distribusi buku dilakukan secara digital, siswa diberi kebebasan untuk mengolah buku sesuai dengan pemikirannya.

A. Bagian pendahuluan terdiri dari bagian :

1) Halaman cover judul yang berisi judul buku dan keterangan penyusun,

2) Cover dalam dan keterangan waktu pembuatan buku.

3) Halaman catatan pembuka yang berisi tentang tujuan dibuatnya buku jurnal pembelajaran tersebut. Pada bagian ini berisi informasi mengenai tujuan dibuatnya buku ini. Pada catatan pembuka dijelaskan pula bahwa buku ini merupakan catatan perjalanan siswa dalam mempelajari Mata Kuliah Metodologi Desain. 


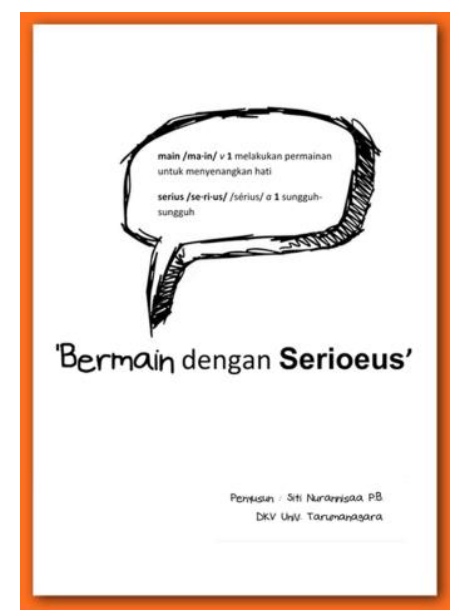

Gambar 1. Halaman Cover Judul dan Halaman catatan pembuka Desain Buku Jurnal 'Bermain Dengan Serioeus'

[Sumber: dokumen penulis]

B. Bagian pertama ; terdiri dari :

1) Halaman petunjuk penggunaan yang menjelaskan mengenai hal apa saja yang akan dilakukan bersama kelompok menggunakan buku jurnal ini. Siswa diberi kebebasan dalam mengekspresikan pemikirannya, namun harus tetap dalam koridor materi yang telah dipelajari dalam kelas.

2) Halaman pertanyaan Materi I : Pengenalan pengertian, lingkup dan fungsi Desain

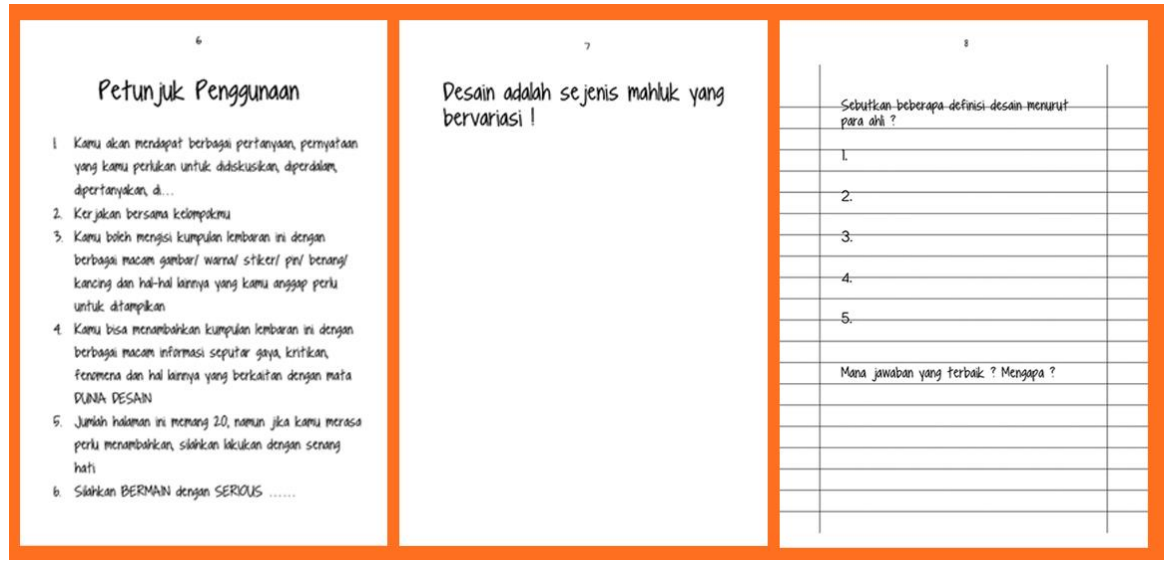

Gambar 2. Halaman Petunjuk dan Materi I, Desain Buku Jurnal 'Bermain Dengan Serioeus' [Sumber: dokumen Penulis]

Bagian ini ini siswa diminta untuk dapat menjabarkan beberapa daftar pengertian desain menurut para ahli. Menggambarkan urutan beberapa deskripsi dari lingkup desain. Pertanyaan ini untuk mengetahui sejauh mana siswa memiliki pengetahuan tentang definisi desain, yang kemudian dikombinasikan dengan pengalaman mereka, Kemudian siswa harus memilih bagian mana yang menurut mereka menjelaskan pendapat terbaik. Bagian ini mulai mengajak siswa untuk dapat memahami suatu materi dan merefleksikan dengan pengalaman yang dimilikinya. Memilih, akan melatih mereka untuk dapat berpikir kritis dan cakap dalam mengambil keputusan. 
C. Bagian kedua ; terdiri dari halaman pertanyaan Materi II : Mengidentifikasikan definisi desain dan metodologi.

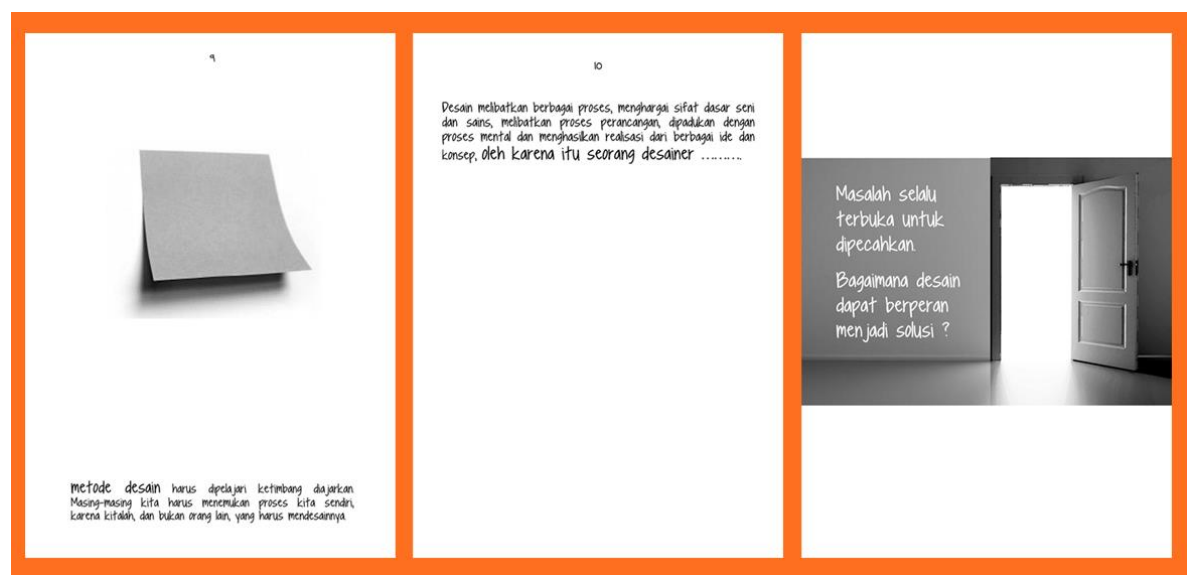

Gambar 3. Halaman Materi II, Desain Buku Jurnal 'Bermain Dengan Serioeus'

[Sumber: dokumen penulis)

Pada bagian ini siswa diminta untuk merespon suatu pernyataan dan pertanyaan yang memunculkan pendapat dan pengalaman tentang pengetahuan definisi desain, arti metodologi dan latar belakang mengapa metodologi dibutuhkan. Dalam menjabarkan jawaban, siswa diarahkan untuk dapat meluaskan arah pandangan. Tidak ada jawaban yang benar atau salah. Jawaban yang diharapkan adalah bagaimana siswa dapat mengeluarkan kemampuan untuk membandingkan, menganalisa, melihat dari sudut pandang yang berbeda dari informasi yang mereka miliki dan merumuskannya kembali menjadi sebuah pernyataan.

D. Bagian ketiga ; terdiri dari halaman pertanyaan Materi III : Pekerjaan dan Kompetensi desainer. Desainer, seniman, atau pekerja teknis.

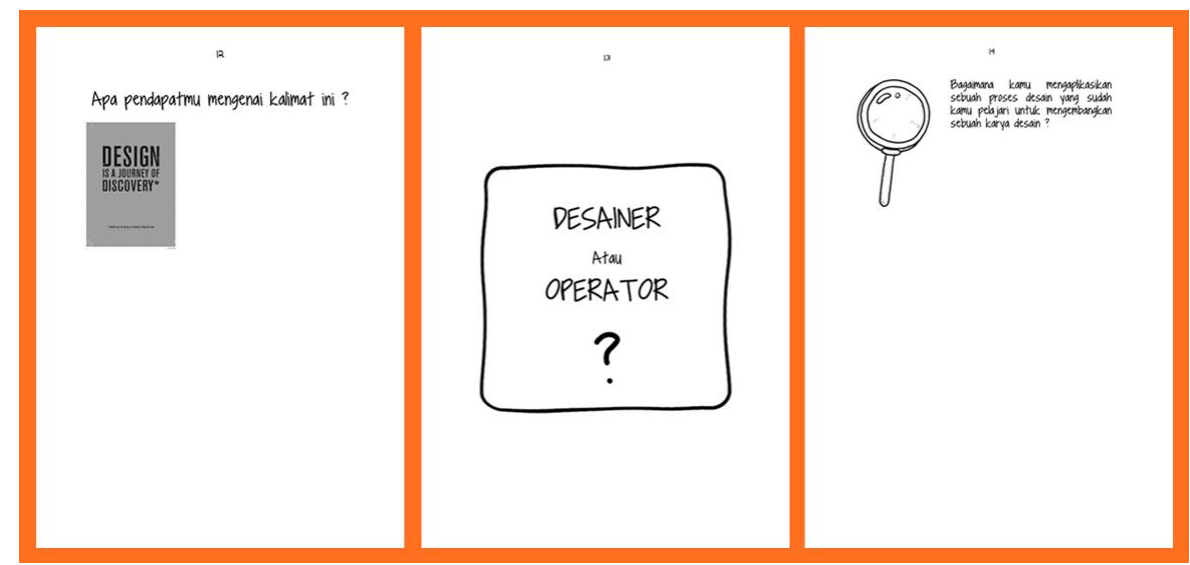

Gambar 4. Halaman Materi III, Desain Buku Jurnal 'Bermain Dengan Serioeus' [Sumber: dokumen penulis]

Bagian ini mencoba untuk melihat deskripsi pekerjaan dan kemampuan apa saja yang harus dimiliki seorang desainer. Bagian apa saja perbedaan peran antara desainer, 
seniman, atau pekerja teknis. Bagian ini mencoba untuk membuat melihat lingkungan, hubungan, dari referensi dan kejadian yang berkembang di dunis desain saat ini. Siswa dapat menjelaskan dalam berbagai format. Pertanyaannya membantu mereka untuk mengidentifikasi peran desainer, bagiamana perbedaan dalam pekerjaan desain, dan mencari lagi informasi lebih dalam dengan cara mereka sendiri. Diharapkan siswa dapat meningkatkan kemampuan untuk melihat dan merasakan proses pekerjaan desain. Menemukan makna dalam sebuah proses desain dari diri mereka sendiri.

E. Bagian keempat ; terdiri dari halaman pertanyaan Materi IV : Mengidentifikasi proses desain dan Pembuatan Konsep Desain.

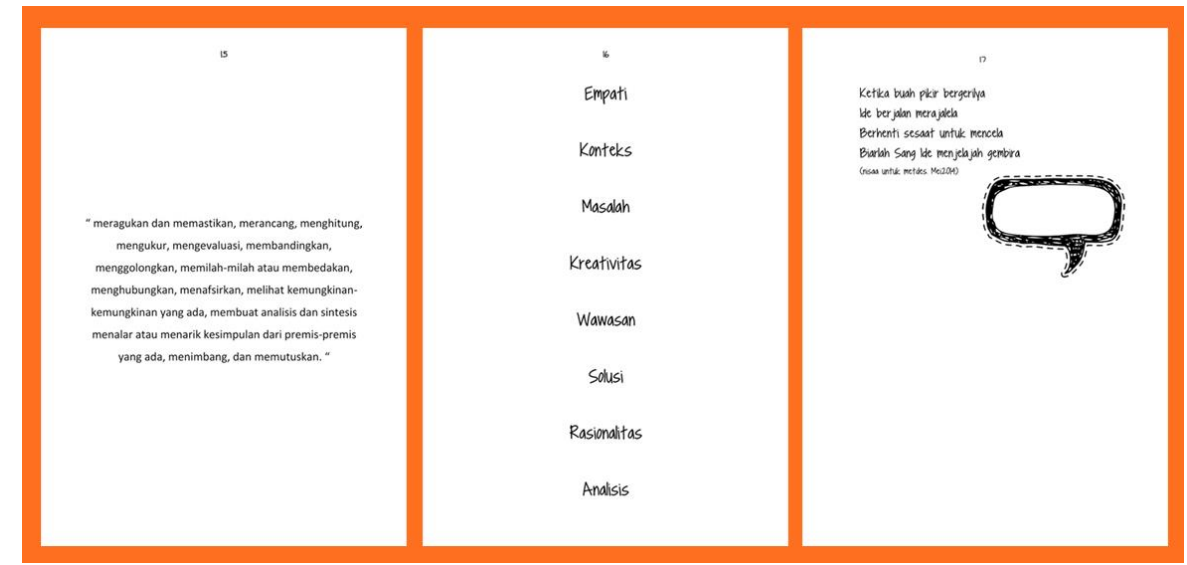

Gambar 5. Halaman Materi IV, Desain Buku Jurnal 'Bermain Dengan Serioeus' [Sumber: dokumen penulis]

Pada bagian ini siswa diminta membuat rumusan identifikasi mengenai hal-hal apa saja yang akan dilakukan dalam sebuah proses desain. Siswa diberi beberapa kata kunci terakit proses desain. Siswa boleh menjelaskan arti kata tersebut, atau merespon kata sesuai dengan sudut pandangnya sendiri. Jika deskripsi kata kunci ini dijelaskan melalui pemaparan dikelas maka informasi cenderung akan hilang atau berhenti pada tataran hafalan. Namun menemukan suatu definisi atau pengertian sendiri dampaknya akan lebih baik dalam membangun pemahaman, pemikiran kritis dan pengembangan sikap ingin tahu. Apabila nanti terdapat pengertian yang kurang tepat, bisa menjadi pembahasan untuk materi diskusi dalam kelas dan menjadi proses refleksi bagi seluruh siswa pada mata kuliah tersebut. 
F. Bagian kelima ; terdiri dari halaman pertanyaan Materi $V$ : Tahapan prosedur pembuatan konsep desain.

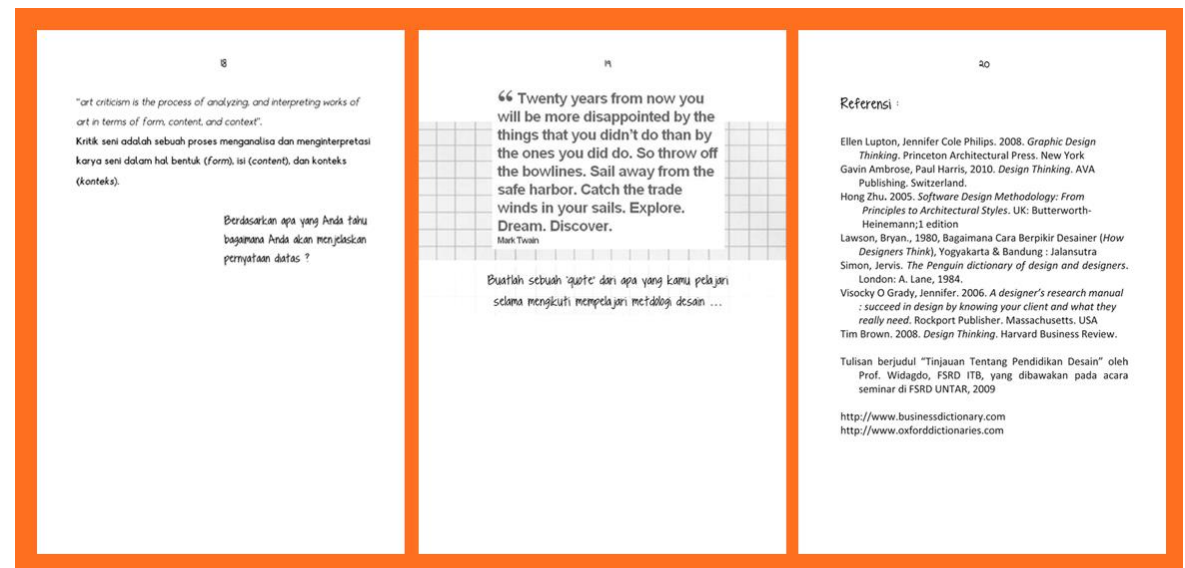

Gambar 6. Halaman Materi IV, Desain Buku Jurnal 'Bermain Dengan Serioeus'

[Sumber: dokumen penulis]

Bagian ini memberikan kesempatan siswa untuk mengeksplorasi dan membuat deskripsi mengenai prosedur pembuatan konsep desain. Rumusan tersebut dapat dibuat apabila siswa memahami pengetahuan pada materi sebelumnya. Siswa didorong untuk memberikan pendapat, pernyataan, pemikiran baru dan membuat kesimpulan menggunakan sudut pandang mereka sendiri. Bagian ini nantinya diharapkan dapat mengetahui bagaimana keterlibatan aktif siswa dalam pembelajaran. Jawaban yang diberikan akan menunjukkan bagaimana kemampuan dalam refleksi dan pemikiran yang dimiliki siswa. Jika variasi jawaban mendukung ekspresi diri dan pemahaman mengenai materi yang disampaikan, maka diharapkan terjadi proses pengembangan pribadi dan pemberdayaan dirinya. Sebuah pernyataan sederhana yang dapat menjadi cerminan diri dan sumber kekuatan yang saat ini dikenal dengan istilah 'quotes' (yang dalam bahasa Indonesia berarti 'tanda kutip/kutipan') menjadi tugas pada halaman terakhir. 'Quotes' dapat mencerminkan bagaimana siswa melihat dirinya dalam mempelajari sebuah proses desain di mata kuliah Metodologi Desain.

\section{KESIMPULAN}

Dalam mempelajari sebuah proses desain, melibatkan proses mental si perancang (desainer) itu sendiri. Mempelajari proses desain sama dengan mempelajari dan mengenal diri sendiri. Jurnal Pembelajaran menjadi salah satu media pembelajaran yang memiliki kemampuan untuk menstimulasi siswa dalam mengeksplorasi dirinya, melalui proses refleksi. Dengan refleksi proses pembelajaran akan lebih bermakna dan siswa lebih mudah dalam membangun pengetahuannya sendiri. Mengaktifkan siswa secara langsung menggunakan media ini dapat membuat perbedaan terhadap gaya belajar dari membaca buku atau penggunaan metode pembelajaran satu arah. Jurnal Pembelajaran membangun rasa ingin tahu, memudahkan dalam memahami bagaimana sebuah proses bekerja dalam dirinya, dan membangkitkan keberanian dalam mengungkapkan gagasan atau pernyataan baru. Mengidentifikasi pengalaman, pemikiran, pengambilan keputusan, kemampuan memilah-memilih, dan eksplorasi kepribadian akan sangat berkaitan dengan mental seorang desainer. Semakin 
seseorang mengenal dirinya, maka semakin mudah pula untuk bisa mendalami sebuah proses desain.

Jurnal pembelajaran memiliki potensi untuk meningkatkan minat dan keterlibatan siswa dengan materi pelajaran. Membangun proses pembelajaran yang bermakna dengan membantu siswa untuk membangun pengetahuan mereka sendiri dengan lebih reflektif dalam studi. Dengan media ini diharapkan siswa lebih mudah memahami bagaimana melihat pengalamannya sendiri dalam proses desain. Belajar proses desain tidak lagi berjarak. Karena mempeajari proses desain bukan sekedar mempelajari materi perkuliahan dalam kelas, tapi ini adalah belajar tentang 'aku, saya' sebagai calon seorang desainer.

\section{DAFTAR PUSTAKA}

Ambrose, G. \& Harris, P. 2010. Design Thinking. London: AVA Publishing.

Ausubel, D. P. 1960. The Use of Advance Organizers in the Learning and Retention of Meaningful Verbal Material. Journal of Educational Psychology, Vol 51(5),pp. 267-272.

Lawson, B. 1980. Bagaimana Cara Berpikir Desainer (How Designers Think). Yogyakarta \& Bandung : Jalansutra.

Lew, D. N. M. \& Schmidt, H. G. 2011. Writing to learn: can reflection journals be used to promote self-reflection and learning?. Higher Education Research \& Development, 30:4, pp.519-532, DOI: 10.1080/07294360.2010.512627.

Moon, J. A. 2006. Learning Journals. New York: Routledge.

Park, C. 2003. Engaging Students in the Learning Process: the learning journal. Journal of Geography in Higher Education, Vol.27.No.2, pp.183-199, DOI: 10.1080/0309826032000107496.

Sadiman, A. 2009. Media Pendidikan, Pengertian, Hakikat, Pengembangan, Pemanfaatan. Jakarta: Raja Grafindo Persada.

Sugiono. 2010. Metode Penelitian Pendidikan: Pendekatan Kuantitatif, Kualitatif dan $R \& D$. Bandung: Alfabeta.

Warsita, B. 2008. Teknologi Pembelajaran, Landasan dan Aplikasinya. Jakarta: Rineka Cipta. 